\title{
Effect of LZSA Glass-Ceramic Addition on Pressureless Sintered Alumina. Part I: Grain Growth
}

\author{
Oscar Rubem Klegues Montedo ${ }^{*}$, Pâmela Cabreira Milak ${ }^{a}$, Cristian Arnaldo Faller ${ }^{b}$, \\ Michael Peterson ${ }^{a}$, Elídio Angioletto ${ }^{a}$, Agenor de Noni Jr. ${ }^{a}$ \\ ${ }^{a}$ Programa de Pós-Graduação em Ciência e Engenharia de Materiais - PPGCEM, Universidade do \\ Extremo Sul Catarinense - UNESC, Av. Universitária, 1105, Cx. P. 3167, Criciúma, SC, Brazil \\ ${ }^{b}$ Curso de Engenharia Mecânica, Universidade do Extremo Sul Catarinense - UNESC, \\ Criciúma, SC, Brazil
}

Received: December 10, 2016; Accepted: May 21, 2017

\begin{abstract}
The aim of this study was to evaluate the effect of an $11.6 \mathrm{Li}_{2} \mathrm{O}-16.8 \mathrm{ZrO}_{2}-68.2 \mathrm{SiO}_{2}-3.4 \mathrm{Al}_{2} \mathrm{O}_{3}(\mathrm{LZSA})$ glass ceramic on the grain growth of alumina obtained by pressureless sintering. Three contents of the LZSA glass ceramic $(7,15$, and $21 \mathrm{vol} \%$; mean particle size of $1.52 \mu \mathrm{m})$ and three types of alumina (mean particle sizes of $0.5,1.7$, and $2.8 \mu \mathrm{m}$ ) were used. The powder compositions were formed by cold pressing. The samples $(5 \mathrm{~mm} \times 5 \mathrm{~mm} \times 13 \mathrm{~mm})$ were sintered in an optical dilatometer. The grain size and morphology were evaluated by scanning electron microscopy. The results show that elongated alumina particles were obtained for the investigated composites compared with pure alumina because of the LZSA addition. The grain growth of alumina was less pronounced at higher LZSA contents. High relative densities were obtained for higher LZSA contents at lower temperatures and holding times compared with pure alumina.
\end{abstract}

Keywords: Alumina, LZSA glass ceramic, Pressureless sintering, Grain growth

\section{Introduction}

Grain-refining processes have recently attracted considerable attention ${ }^{1,2}$ because they significantly affect the final properties of the material. For instance, nanometer-grained ceramics can show significant elongation before breaking at moderate temperatures $\left(0.5 \mathrm{~T}_{\mathrm{m}}\right)^{3}$.

Ultrafine ceramics have been mainly obtained by inhibiting the growth of ultrafine grains $(<300 \mathrm{~nm})$ during processing. Moreover, the attainment of a fully dense ceramic plays an important role for achieving useful mechanical ${ }^{4}$, optical ${ }^{5}$ and magnetic properties ${ }^{6}$.

Fully dense polycrystalline ceramics has been successfully obtained by different processing routes, such as conventional sintering, hot pressing, hot isostatic pressing, microwaveassisted sintering ${ }^{7}$, spark-plasma sintering ${ }^{8,9}$, and millimeterwave radiation ${ }^{10}$. However, the suppression of grain growth also plays a crucial role. For example, the grain size has been considered as the main microstructural aspect related to the mechanical properties of alumina ${ }^{11,12}$. In this sense, two-step sintering has been successfully used to obtain dense alumina at low temperatures while suppressing grain growth at the end of sintering ${ }^{13,14}$.

The suppression of grain growth of alumina can also be achieved through liquid phase sintering (LPS), which is typically performed at high temperatures $\left(>1,600^{\circ} \mathrm{C}\right)^{15}$.

* e-mail: oscar.rkm@gmail.com
However, special attention must be paid to the phases formed from the liquid phase. Glassy materials, for example, help to increase densification but form a vitreous, fragile phase during cooling, reducing the fracture toughness and, in most cases, the wear resistance. To overcome this limitation of ordinary glasses, glass ceramics can be used, as the parent glass can act as a very low-viscosity liquid phase with a high wettability, densifying the alumina at lower sintering temperatures and hence suppressing grain growth of alumina. Additionally, the nature and amounts of crystalline phases formed during the cooling should produce a strong interface with alumina particles, improving the mechanical properties ${ }^{16}$.

$\mathrm{Li}_{2} \mathrm{O}-\mathrm{ZrO}_{2}-\mathrm{SiO}_{2}-\mathrm{Al}_{2} \mathrm{O}_{3}$ (LZSA) glass ceramics achieve maximum densification at low temperatures $\left(800-850{ }^{\circ} \mathrm{C}\right)^{17,18}$ and crystallize to form mostly $\beta$-spodumene ss $_{\text {s }}$ (solid solution, $\left.\mathrm{Li}_{2} \mathrm{O} \cdot \mathrm{Al}_{2} \mathrm{O}_{3} \cdot 4-10 \mathrm{SiO}_{2}\right)$ and zirconium silicate $\left(\mathrm{ZrSiO}_{4}\right)$ as crystalline phases ${ }^{19,20}$. Their low coefficient of thermal expansion (CTE) compared with alumina can create compressive stresses in the glass ceramic/alumina interface, strengthening the obtained composite and improving mechanical properties such as the wear resistance ${ }^{21}$.

Thus, Part I of this work aims to demonstrate the effect of an LZSA glass ceramic on the grain growth of alumina.

\section{Experimental}

Chemical composition, specific surface area and mean particle size $\left(d_{50}\right)$ of the materials used in this work-an 
11.6 $\mathrm{Li}_{2} \mathrm{O}-16.8 \mathrm{ZrO}_{2}-68.2 \mathrm{SiO}_{2}-3.4 \mathrm{Al}_{2} \mathrm{O}_{3}$ glass ceramic (Tecnofrita Produtos Cerâmicos Ltda, Brazil) and alumina (Almatis, USA) - are shown in Table 1. Table 2 shows the composition and $d_{50}$ of alumina ceramics and composites. The compositions were prepared using statistical planning considering two factors - $d_{50}$ and the LZSA content - which were varied between two levels $(-1$ and +1$)$, establishing a $2^{2}$ factorial design with three central points $\left(A_{M} 15\right)$.

Table 1. Chemical and physical characteristics of the used powders.

\begin{tabular}{|c|c|c|c|c|}
\hline \multirow{3}{*}{ Oxides } & \multicolumn{4}{|c|}{ Content (wt $\%$ ) } \\
\hline & \multirow[b]{2}{*}{ LZSA } & \multicolumn{3}{|c|}{ Alumina code } \\
\hline & & $\begin{array}{c}\text { A } 16 \text { SG } \\
\left(A_{F}\right)\end{array}$ & $\begin{array}{c}\text { A } 15 \text { SG } \\
\left(A_{M}\right)\end{array}$ & $\begin{array}{l}\text { A } 3500 \\
\text { SG }\left(A_{C}\right)\end{array}$ \\
\hline $\mathrm{Al}_{2} \mathrm{O}_{3}$ & 6.63 & 99.8 & 99.8 & 99.8 \\
\hline $\mathrm{Na}_{2} \mathrm{O}$ & 3.74 & 0.07 & 0.07 & 0.07 \\
\hline $\mathrm{Fe}_{2} \mathrm{O}_{3}$ & 0.25 & 0.02 & 0.02 & 0.02 \\
\hline $\mathrm{MgO}$ & - & 0.05 & 0.04 & $<0.01$ \\
\hline $\mathrm{SiO}_{2}$ & 65.15 & 0.03 & 0.02 & 0.02 \\
\hline $\mathrm{CaO}$ & 0.13 & 0.02 & 0.03 & 0.03 \\
\hline $\mathrm{B}_{2} \mathrm{O}_{3}$ & 4.57 & $<0.01$ & $<0.01$ & $<0.01$ \\
\hline $\mathrm{Li}_{2} \mathrm{O}$ & 8.98 & - & - & - \\
\hline $\mathrm{TiO}_{2}$ & 0.06 & - & - & - \\
\hline $\mathrm{ZrO}_{2}$ & 8.75 & - & - & - \\
\hline Loss on Ignition & 1.72 & - & - & - \\
\hline \multicolumn{5}{|l|}{$\begin{array}{l}\text { Physical } \\
\text { Properties }\end{array}$} \\
\hline $\begin{array}{l}\text { Specific surface } \\
\text { area }\left(\mathrm{m}^{2} \cdot \mathrm{g}^{-1}\right)\end{array}$ & 8.36 & 8.9 & 4.9 & 1.9 \\
\hline$d_{50}(\mu \mathrm{m})$ & 1.42 & 0.5 & 1.7 & 2.8 \\
\hline
\end{tabular}

Table 2. Experimental design with the combinations among each factor.

\begin{tabular}{lccc}
\hline \multirow{2}{*}{ Material code } & $\begin{array}{c}d_{50}(\mu \mathrm{m}) \text { of } \\
\text { alumina }\end{array}$ & \multicolumn{2}{c}{ LZSA } \\
\cline { 3 - 4 } & 0.5 & 0 & $(\mathrm{vol} \%)$ \\
$\mathrm{A}_{\mathrm{F}}$ & 1.7 & 0 & 0 \\
$\mathrm{~A}_{\mathrm{M}}$ & 2.8 & 0 & 0 \\
$\mathrm{~A}_{\mathrm{C}}$ & 0.5 & 7 & 5 \\
$\mathrm{~A}_{\mathrm{F}} 7$ & 2.8 & 7 & 5 \\
$\mathrm{~A}_{\mathrm{C}} 7$ & 0.5 & 21 & 15 \\
$\mathrm{~A}_{\mathrm{F}} 21$ & 2.8 & 21 & 15 \\
$\mathrm{~A}_{\mathrm{C}} 21$ & 1.7 & 15 & 10 \\
$\mathrm{~A}_{\mathrm{M}} 15-1$ & 1.7 & 15 & 10 \\
$\mathrm{~A}_{\mathrm{M}} 15-2$ & 1.7 & 15 & 10 \\
$\mathrm{~A}_{\mathrm{M}} 15-3$ & & & \\
\hline
\end{tabular}

Composites were prepared by wet-milling and dried to obtain powders ( $5 \mathrm{wt} \%$ moisture) containing $1 \mathrm{wt} \%$ of carboximethilcelulose as a binder. The powders were pressed in a hydraulic press (Gabbrielli GT 0785, Italy; $128 \mathrm{MPa}$ specific pressure), and the resulting compact bodies were dried $\left(110 \pm 5^{\circ} \mathrm{C} / 3 \mathrm{~h}\right)$. The green densities ranged from 1.92 to $2.61 \mathrm{~g} \cdot \mathrm{cm}^{-3}$ (green relative densities ranging from 0.509 to 0.654$)$ depending on the LZSA content. The sintering behavior of the green bodies $(5 \mathrm{~mm} \times 5 \mathrm{~mm} \times 13 \mathrm{~mm})$ was investigated by optical dilatometry (Expert System Solutions S.R.L. model Misura HSM ODHT 1400 , Italy; $10^{\circ} \mathrm{C} \cdot \mathrm{min}^{-1}$ in air, maximum temperature of $1,600^{\circ} \mathrm{C}$ ).

The relative densities $\left(d_{r e l}\right)$ of the sintered bodies were calculated according to the relationship between the bulk density and the theoretical density. The bulk density $\left(d_{b u l k}\right)$ was determined by water immersion $\left(22^{\circ} \mathrm{C}\right)$. The theoretical density $\left(d_{t}\right)$ of the pure alumina and the LZSA glass ceramic $\left(2.52 \mathrm{~g} \cdot \mathrm{cm}^{-3}\right)$ were determined by He-pycnometry (Quantachrome Ultrapyc 1200e, USA). The theoretical density $\left(d_{t}\right)$ of the composites was estimated by mixture rule of the components, considering the $d_{t}$ values of the alumina and the LZSA glass ceramic.

The microstructures of the sintered compositions were observed with a scanning electron microscope (Zeiss EVO MA10, Germany) using specimens that were cut, polished, etched ( 2 vol\% HF, $25 \mathrm{~s}$ ), and coated with a thin Au film. The chemical etching was performed to eliminate the glass ceramic existing in the surface of the samples and hence allow the visualization of the grain morphology. The average grain size of the alumina was determined using the line-intercept method with at least 50 intercepts for each analyzed image ${ }^{22}$.

\section{Results and Discussion}

The main objective of adding the LZSA glass ceramic to alumina was to densify it at lower temperatures and holding times in order to suppress the grain growth. Moreover, this glass ceramic forms specific crystalline phases from the glassy phase during controlled cooling, which can establish compressive stress in the interface between the glass ceramic and alumina grains. Thus, the mechanical properties are improved, as shown in Part II of this work.

According to a previous work ${ }^{21}$, the use of LZSA helps alumina to densify by LPS. The temperature for sintering initiation (SI) decreased with the addition of the glass ceramic. However, the SI does not depend on the grain size of alumina or the LZSA content. On the other hand, the maximum linear shrinkage $\left(\mathrm{LS}_{\max }\right)$ was dependent of the LZSA content. Alumina $\mathrm{A}_{\mathrm{F}}$ and the composites $\mathrm{A}_{\mathrm{F}} 7$ and $\mathrm{A}_{\mathrm{F}} 21$ achieved $\mathrm{LS}_{\max }$ at different temperatures and holding times, i.e., $14.3 \%\left(1,600{ }^{\circ} \mathrm{C} / 10 \mathrm{~h}\right), 18.5\left(1,600{ }^{\circ} \mathrm{C} / 8 \mathrm{~h}\right)$, and $18.7 \%\left(1,470{ }^{\circ} \mathrm{C} / 3 \mathrm{~h}\right)$, respectively. According to this sintering behavior, different sintering temperatures and holding times were chosen for each alumina and composite (Table 3) in order to achieve high level of densification with no significant grain growth.

As shown in Table 3, pure alumina showed low densification at $1,600^{\circ} \mathrm{C}$. On the other hand, the composites achieved higher densification than the pure alumina at the same sintering temperature or lower. For the same LZSA 
Table 3. Sintering conditions (temperature, $\mathrm{T}$, and holding time, $\mathrm{t}$ ) and properties of the sintered alumina and composites (estimated theoretical density, $\mathrm{d}_{\mathrm{t}}$, bulk density, $\mathrm{d}_{\text {bulk }}$, relative density, $\mathrm{d}_{\text {rel }}$, and maximum linear shrinkage, $\mathrm{LS}_{\max }$ ).

\begin{tabular}{lcccccc}
\hline \multirow{2}{*}{ Material code } & \multicolumn{5}{c}{ Sintering conditions } & \multicolumn{3}{c}{ Properties of the sintered specimens } \\
\cline { 2 - 6 } & $\mathrm{T}\left({ }^{\circ} \mathrm{C}\right)$ & $\mathrm{t}(\mathrm{h})$ & $d_{t}\left(\mathrm{~g} / \mathrm{cm}^{3}\right)$ & $d_{\text {bulk }}\left(\mathrm{g} / \mathrm{cm}^{3}\right)$ & $d_{\text {rel }}(\%)$ & $\mathrm{LS}_{\max }(\%)$ \\
\hline $\mathrm{A}_{\mathrm{F}}$ & 1600 & 4 & 3.85 & $3.55 \pm 0.02$ & 92.2 & 7.8 \\
$\mathrm{~A}_{\mathrm{M}}$ & 1600 & 7 & 3.79 & $3.22 \pm 0.02$ & 85.0 & 7.3 \\
$\mathrm{~A}_{\mathrm{C}}$ & 1600 & 10 & 3.79 & $2.84 \pm 0.07$ & 74.9 & 7.2 \\
$\mathrm{~A}_{\mathrm{F}} 7$ & 1600 & 4 & 3.72 & $3.53 \pm 0.03$ & 94.9 & 18.9 \\
$\mathrm{~A}_{\mathrm{C}} 7$ & 7 & 3.70 & $3.55 \pm 0.08$ & 95.9 & 12.7 \\
$\mathrm{~A}_{\mathrm{F}} 21$ & 1600 & 3 & 3.51 & $3.44 \pm 0.02$ & 98.0 & 18.2 \\
$\mathrm{~A}_{\mathrm{C}} 21$ & 1470 & 0.67 & 3.50 & $3.33 \pm 0.06$ & 95.1 & 15.2 \\
$\mathrm{~A}_{\mathrm{M}} 15$ & 1600 & 3 & 3.61 & $3.47 \pm 0.05$ & 96.1 & 16.8 \\
\hline
\end{tabular}

content, the highest density values were obtained for the fine-grained alumina, as reported by Roy et al. ${ }^{11}$.

Thus, the glass ceramic allowed the alumina to densify at lower temperatures and holding times. Because of this, the grain growth was suppressed.

Regarding the investigated composites, two effects of the LZSA addition to alumina on the suppression of the alumina grain growth must be considered: the lowering of the sintering temperature and the holding time and the reduction of contact (barrier to diffusion) among alumina grains because of the glass ceramic.

According to previous works ${ }^{17,18,20}$, the sintering of the LZSA glass ceramic occurs from $\sim 500$ to $900^{\circ} \mathrm{C}$, depending on the chemical composition. Melting was observed in the range of $1,020-1,075^{\circ} \mathrm{C}$. Thus, the viscosity of the formed glassy phase was significantly diminished at higher temperatures, promoting the densification of alumina by $\mathrm{LPS}^{21}$.

The suppression of the grain growth must be evaluated for the mechanical properties to be improved. Figure 1 clearly shows the effect of reducing the sintering temperature on the microstructure. Comparing the alumina $A_{F}$ and the composite $A_{F} 7$ sintered at the same conditions $\left(1,600^{\circ} \mathrm{C} / 4\right.$ h) reveals that the densification was higher for the last one. However, the composite $\mathrm{A}_{\mathrm{F}} 21$ was sintered at a far lower temperature $\left(1,470^{\circ} \mathrm{C}\right)$ and holding time $(3 \mathrm{~h})$ than $\mathrm{A}_{\mathrm{F}} 7$ for almost the same densification. Nevertheless, the grain sizes of alumina were roughly the same.

Similar results were obtained for the alumina $A_{M}$ and the composite $\mathrm{A}_{\mathrm{M}} 15$ regarding the microstructure (Figure 2). However, Table 3 shows that the relative density was higher for the composite. This means that for the same densification level, the composite $A_{M} 15$ densified at a lower temperature than the respective pure alumina $\left(\mathrm{A}_{\mathrm{M}}\right)$.

The same behavior was observed for the alumina $\mathrm{A}_{C}$ and composites $\mathrm{A}_{\mathrm{C}} 7$ and $\mathrm{A}_{\mathrm{C}} 21$ but with important microstructural changes (Figure 3 ). The LZSA addition significantly improved the densification of $A_{C}$. Compared with the composite $A_{C} 7, A_{C} 21$ exhibited a similar relative density at the same temperature but at a far lower holding time - only $40 \mathrm{~min}$, compared with

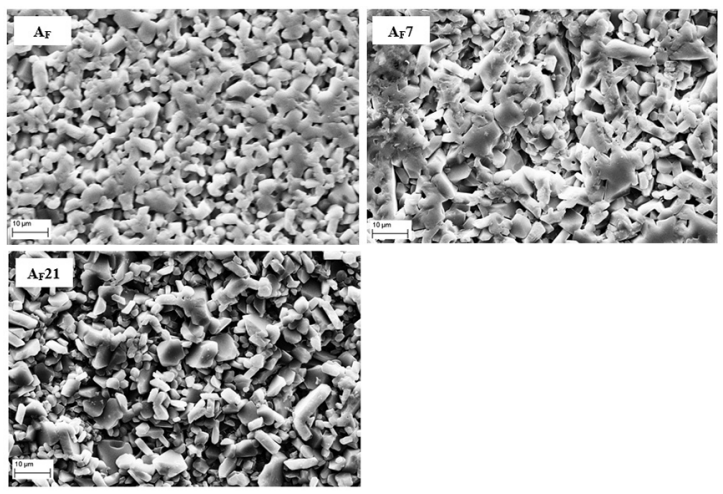

Figure 1. SEM observations of alumina $\mathrm{A}_{\mathrm{F}}\left(1,600{ }^{\circ} \mathrm{C} / 4 \mathrm{~h}, d_{r e l}=\right.$ $0.92)$ and composites $\mathrm{A}_{\mathrm{F}} 7\left(1,600^{\circ} \mathrm{C} / 4 \mathrm{~h}, d_{r e l}=0.95\right)$ and $\mathrm{A}_{\mathrm{F}} 21$ $\left(1,470{ }^{\circ} \mathrm{C} / 3 \mathrm{~h}, d_{r e l}=0.98\right)$.

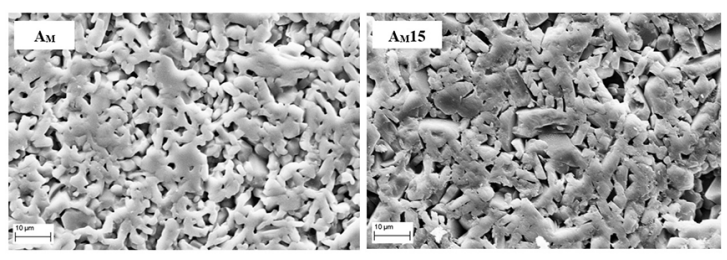

Figure 2. SEM observations of alumina $\mathrm{A}_{\mathrm{M}}\left(1,600^{\circ} \mathrm{C} / 7 \mathrm{~h}, d_{r e l}=\right.$ $0.85)$ and composite $\mathrm{A}_{\mathrm{M}} 15\left(1,600^{\circ} \mathrm{C} / 3 \mathrm{~h}, d_{\text {rel }}=0.96\right)$.

$7 \mathrm{~h}$ for $\mathrm{A}_{\mathrm{C}} 7$. Nevertheless, as shown in Figure 3, elongated alumina grains were obtained compared with the pure coarse alumina $\left(\mathrm{A}_{\mathrm{C}}\right)$ because of the LZSA addition. Moreover, the grain growth was suppressed. Table 4 shows the average grain size of alumina for pure alumina and composites. Although a very high standard deviation was observed, we see that the average grain size of $21 \mathrm{vol} \%$ LZSA-based composites is similar to that of pure alumina. However, the alumina grain size can be lower in the composite compared with pure alumina of the same relative density.

Because of these features (smaller and elongated grains), the mechanical strength of the alumina is improved ${ }^{23}$.

The effect of the holding time on the grain growth for the composite $A_{C} 21$ is shown in Figure 4. Significant grain growth with the increase of the holding time is observed, 


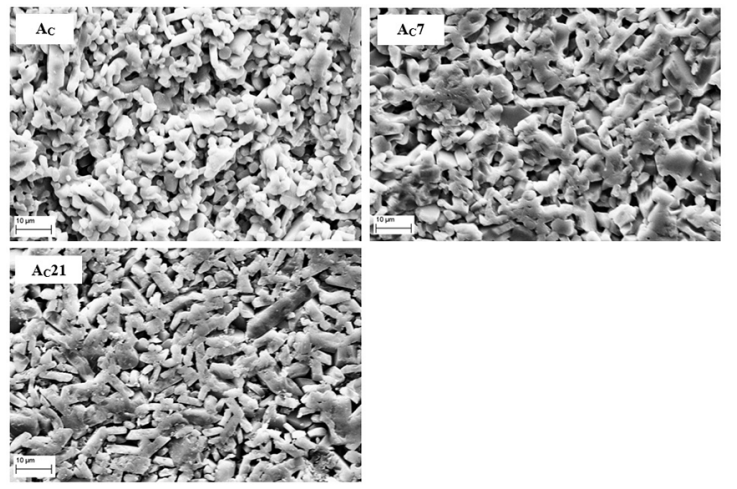

Figure 3. SEM observations of alumina $\mathrm{A}_{\mathrm{C}}\left(1,600^{\circ} \mathrm{C} / 10 \mathrm{~h}, d_{r e l}\right.$ $=0.75)$ and composites $\mathrm{A}_{\mathrm{C}} 7\left(1,600{ }^{\circ} \mathrm{C} / 7 \mathrm{~h}, d_{\text {rel }}=0.96\right)$ and $\mathrm{A}_{\mathrm{C}} 21$ $\left(1,600{ }^{\circ} \mathrm{C} / 40 \mathrm{~min}, d_{r e l}=0.96\right)$.

Table 4. Average grain size of alumina in pure alumina and composites.

\begin{tabular}{lccc}
\hline \multirow{2}{*}{$\begin{array}{l}\text { LZSA content } \\
\text { (vol\%) }\end{array}$} & \multicolumn{3}{c}{ Alumina } \\
\cline { 2 - 4 } & $\mathrm{A}_{\mathrm{F}}$ & $\mathrm{A}_{\mathrm{M}}$ & $\mathrm{A}_{\mathrm{C}}$ \\
\hline 0 & $3.10 \pm 3.20$ & $5.66 \pm 3.69$ & $6.39 \pm 5.09$ \\
7 & $15.05 \pm 17.33$ & & $16.14 \pm 17.02$ \\
15 & & $7.22 \pm 8.30$ \\
21 & $5.81 \pm 5.05$ & & $6.25 \pm 8.63$ \\
\hline
\end{tabular}

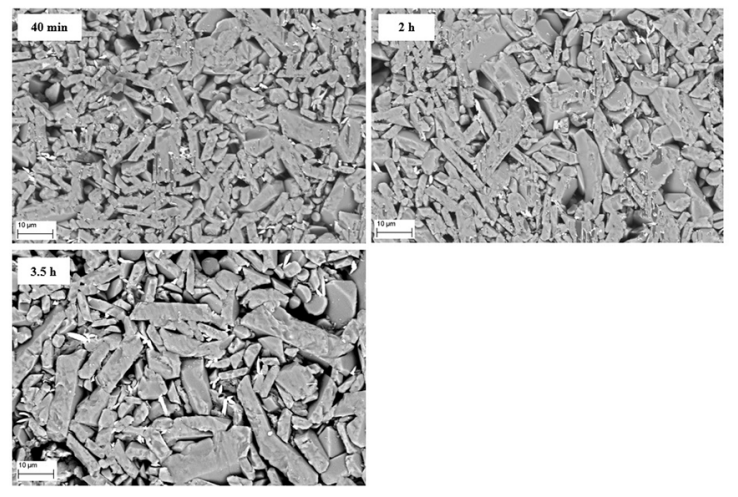

Figure 4. SEM observations of composite $\mathrm{A}_{\mathrm{C}} 21$ sintered at 1,600 ${ }^{\circ} \mathrm{C}$ and different holding times (40 min, $d_{r e l}=0.95 ; 2 \mathrm{~h}, d_{r e l}=0.96$; and $3.5 \mathrm{~h}, d_{r e l}=0.99$ ).

although no significant increase of the relative density is observed. Thus, a reduction of the holding time for almost the same densification can be obtained because of the LZSA addition, while avoiding the grain growth.

One may consider that the LZSA addition caused the suppression of the grain growth in alumina because of the reduction of the sintering temperature and holding time. Moreover, the LZSA glass ceramic can be considered a barrier to grain growth that acts as an obstacle to the intergranular diffusion.

In this case, the crystallization of $\beta$-spodumene ss $_{\text {si }}$ occurs in the alumina/LZSA interface ${ }^{21}$. With a higher glass-ceramic content, this barrier to grain growth should be increasingly effective and have a better distribution among the alumina grains.
Thus, densification occurred prior to the grain growth, probably because of the barrier existing among alumina grains, caused by the LZSA glass ceramic, and the reduction of the $\mathrm{Al}_{2} \mathrm{O}_{3}$ diffusion.

Considering the same LZSA content and relative densities, Figure 5 shows the effect of the alumina particle size and sintering conditions (temperature and holding time) on the microstructures of the composites $\mathrm{A}_{\mathrm{F}} 21$ and $\mathrm{A}_{\mathrm{C}} 21$. The grain sizes are almost the same, but we observe that

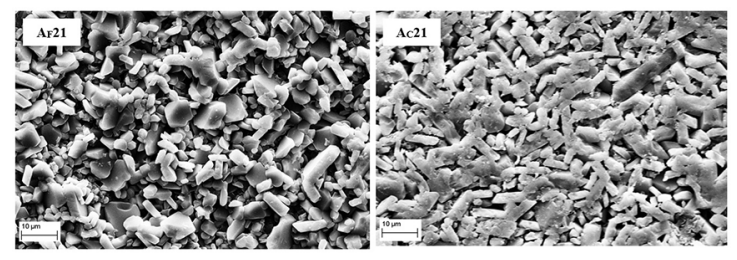

Figure 5. SEM observations of composites $A_{\mathrm{F}} 21\left(1,470{ }^{\circ} \mathrm{C} / 3 \mathrm{~h}\right.$, $\left.d_{r e l}=0.98\right)$ and $\mathrm{A}_{\mathrm{C}} 21\left(1,600^{\circ} \mathrm{C} / 40 \mathrm{~min}, d_{r e l}=0.95\right)$.

- $\quad$ A higher grain growth $\left(d_{50}=0.5 \mu \mathrm{m}\right.$ for $\mathrm{A}_{\mathrm{F}}$ compared with $d_{50}=2.8 \mu \mathrm{m}$ for $\mathrm{A}_{\mathrm{C}}$ ) was obtained at a lower sintering temperature and a higher holding time; and - more elongated grains for $\mathrm{A}_{\mathrm{C}}$ compared with $\mathrm{A}_{\mathrm{F}}$ were obtained at a higher sintering temperature and a lower holding time.

Thus, depending on the required final properties of alumina, the sintering temperature and holding time can be changed to modify the grain shape for close relative-density values.

\section{Conclusions}

We evaluated the effect of the LZSA $\left(11.6 \mathrm{Li}_{2} \mathrm{O}-16.8 \mathrm{ZrO}_{2}\right.$ $68.2 \mathrm{SiO}_{2}-3.4 \mathrm{Al}_{2} \mathrm{O}_{3}$ ) glass ceramic on the grain growth of alumina. The results showed that the LZSA addition to the alumina improved sintering. The 21 vol\% LZSA addition to fine alumina $\left(d_{50}=0.5 \mu \mathrm{m}\right)$ favored the reduction of the sintering temperature and holding time from 1,600 to 1,470 ${ }^{\circ} \mathrm{C}$ and from $10 \mathrm{~h}$ to $40 \mathrm{~min}$, respectively, for the same relative density. Elongated alumina particles were obtained compared with pure alumina because of the LZSA addition. Moreover, the suppression of the grain growth should improve mechanical properties. The grain growth was less pronounced at higher LZSA contents compared with pure alumina. High relative densities were obtained for higher LZSA contents at lower temperatures and holding times.

\section{Acknowledgements}

The authors are very grateful to Conselho Nacional de Desenvolvimento Científico e Tecnológico (CNPq/Brazil) and Financiadora de Estudos e Projetos (FINEP/Brazil) for funding this work. 


\section{References}

1. Suryanarayana C. Mechanical alloying and milling. Progress in Materials Science. 2001;46(1-2):1-184. DOI: 10.1016/ S0079-6425(99)00010-9

2. Bowen P, Carry C, Luxembourg D, Hofmann H. Colloidal processing and sintering of nanosized transition aluminas. Powder Technology. 2005;157(1-3):100-107. DOI: 10.1016/j. powtec.2005.05.015

3. Weibel A, Bouchet R, Bouvier P, Knauth P. Hot compaction of nanocrystalline $\mathrm{TiO}_{2}$ (anatase) ceramics. Mechanisms of densification: Grain size and doping effects. Acta Materialia. 2006;54(13):3575-3583. DOI: 10.1016/j.actamat.2006.03.033

4. Yin Z, Yuan J, Cheng Y, Wang C, Wang Z, Hu X. Microstructure and mechanical properties of $\mathrm{Al}_{2} \mathrm{O}_{3} / \mathrm{Ti}(\mathrm{C}, \mathrm{N})$ ceramic tool materials by one-step and two-step microwave sintering. Materials Science and Engineering: A. 2016;670:159-165. DOI: $10.1016 /$ j.msea.2016.06.015

5. Kim HS, Oh ST, Kim YD. Effects of the two-step sintering process on the optical transmittance and mechanical strength of polycrystalline alumina ceramics. Ceramics International. 2014;40(9 PtA):14471-14475. DOI: 10.1016/j.ceramint.2014.05.127

6. Ebrahimi Y, Sabbagh Alvani AA, Sarabi AA, Sameie H, Salimi R, Sabbagh Alvani M, et al. A comprehensive study on the magnetic properties of nanocrystalline $\mathrm{SrCo}_{0.2} \mathrm{Fe}_{11.8} \mathrm{O}_{19}$ ceramics synthesized via diverse routes. Ceramics International. 2012;38(5):3885-3892. DOI: 10.1016/j.ceramint.2012.01.040

7. Maca K, Pouchlý V, Bodišová K, Švančárek P, Galusek D. Densification of fine-grained alumina ceramics doped by magnesia, yttria and zirconia evaluated by two different sintering models. Journal of the European Ceramic Society. 2014;34(16):43634372. DOI: 10.1016/j.jeurceramsoc.2014.06.030

8. Lee YI, Lee JH, Hong SH, Kim DY. Preparation of nanostructured $\mathrm{TiO}_{2}$ ceramics by spark plasma sintering. Materials Research Bulletin. 2003;38(6):925-930. DOI: 10.1016/S0025-5408(03)00084-9

9. Angerer P, Yu LG, Khor KA, Krumpel G. Spark-plasma-sintering (SPS) of nanostructured and submicron titanium oxide powders. Material Science and Engineering: A. 2004;381(1-2):16-19. DOI: $10.1016 /$ j.msea.2004.02.009

10. Li J, Ye Y, Shen L, Chen L, Zhou H. Densification and grain growth during pressureless sintering of $\mathrm{TiO}_{2}$ nanoceramics. Materials Science and Engineering: A. 2005;390(1-2):265-270. DOI: $10.1016 /$ j.msea.2004.08.025

11. Roy RS, Guchhait H, Chanda A, Basu D, Mitra MK. Improved sliding wear-resistance of alumina with sub-micron grain size: A comparison with coarser grained material. Journal of the European Ceramic Society. 2007;27(16):4737-4743. DOI: 10.1016/j.jeurceramsoc.2007.02.205

12. Hsu YF, Wang SF, Wang YR, Chen SC. Effect of niobium doping on the densification and grain growth in alumina.
Ceramics International. 2008;34(5):1183-1187. DOI: 10.1016/j. ceramint.2007.02.010

13. Wang XH, Chen PL, Chen IW. Two-Step Sintering of Ceramics with Constant Grain-Size, I. $\mathrm{Y}_{2} \mathrm{O}_{3}$. Journal of the American Ceramic Society. 2006;89(2):431-437. DOI: 10.1111/j.15512916.2005.00763.x

14. Hesabi ZR, Haghighatzadeh M, Mazaheri M, Galusek D, Sadrnezhaad SK. Suppression of grain growth in sub-micrometer alumina via two-step sintering method. Journal of the American Ceramic Society. 2009;29(8):1371-1377. DOI: 10.1016/j. jeurceramsoc.2008.08.027

15. Zuo F, Saunier S, Marinel S, Chanin-Lambert P, Peillon N, Goeuriot D. Investigation of the mechanism(s) controlling microwave sintering of $\alpha$-alumina: Influence of the powder parameters on the grain growth, thermodynamics and densification kinetics. Journal of the European Ceramic Society. 2015;35(3):959-970. DOI: $10.1016 /$ j.jeurceramsoc.2014.10.025

16. De Noni Júnior A, Hotza D, Soler VC, Vilches ES. Influence of composition on mechanical behaviour of porcelain tile. Part III: Effect of the cooling rate of the firing cycle. Materials Science and Engineering: A. 2011;528(9):3330-3336. DOI: 10.1016/j. msea.2010.12.086

17. Montedo ORK, Floriano FJ, Oliveira Filho J, Angoletto E, Bernardin AM. Sintering behavior of LZSA glass-ceramics. Materials Research. 2009;12(2):197-200. DOI: 10.1590/S151614392009000200014

18. Montedo ORK, Floriano FJ, Oliveira Filho J. Sintering kinetics of a $18.8 \mathrm{Li}_{2} \mathrm{O} 8.3 \mathrm{ZrO}_{2} 64.2 \mathrm{SiO}_{2} 8.7 \mathrm{Al}_{2} \mathrm{O}_{3}$ glass ceramic. Ceramics International. 2011;37(6):1865-1871. DOI: $10.1016 / \mathrm{j}$. ceramint.2011.03.047

19. Montedo ORK, Bertan FM, Piccoli R, Hotza D, Klein AN, Oliveira APN. Low Thermal Expansion Sintered LZSA GlassCeramics. American Ceramic Society Bulletin. 2008;87(7):34-40.

20. Montedo ORK, Hotza D, Oliveira APN, Meszaros R, Travitzky N, P. Greil P. Crystallisation Kinetics of a $\beta$-Spodumene-Based Glass Ceramic. Advances in Materials Science and Engineering. 2012;2012:525428. DOI: $10.1155 / 2012 / 525428$

21. Montedo ORK, Milak PC, Minatto FD, Nuernberg RB, Faller CA, Oliveira APN, et al. Effect of a LZSA glass-ceramic addition on the sintering behavior of alumina. Journal of Thermal Analysis and Calorimetry. 2016;124(1):241-249. DOI: $10.1007 / \mathrm{s} 10973-015-5144-5$

22. Callister Jr. WD, Rethwisch DG. Ciência e Engenharia de Materiais: Uma Introdução. Rio de Janeiro: LTC; 2013.817 p.

23. Krell A, Blank P, Ma H, Hutzler T, Nebelung M. Processing of High-Density Submicrometer $\mathrm{Al}_{2} \mathrm{O}_{3}$ for New Applications. Journal of the American Ceramic Society. 2003;86(4):546-553. DOI: $10.1111 / \mathrm{j} .1151-2916.2003 . t b 03339 . x$ 